\title{
ANALYSIS OF STUDENTS' WRITING BY USING SURFACE TAXONOMY STRATEGY AT PRE-PLANET PROGRAM OF KRESNA ENGLISH LANGUAGE INSTITUTE
}

\author{
Anisah Ramadhani
}

\begin{abstract}
Considering the importance of grammatical aspect in the writing process, the students should have gramatical knowledge since they are as a beginner. This research aims at error analysis of students' writing by using surface taxonomy strategy and the factors happen in error of students' writing based on surface taxonomy strategy at Pre-Planet Program of Kresna English Language. The research study is classified into qualitative research. The instrument that the researcher used are document and interview. By analyzing the students' answer sheet, the writer obtained their scores of the test result and found that the highest error was found in Misinformation, the students committed 147 times or $68.37 \%$ out of the whole errors. The second is Omission, from the data that was found 37 times or $17.21 \%$ out of the whole errors of omission. Then, Addition was found 27 errors or $12.56 \%$ on their writing. The lowest percentage is Mis ordering, was found 4 times or $1.86 \%$ errors. The factors of those errors because of the students do not know well about how to use the structure of sentence, the vocabulary that the students do not know before even how to spell it. Writing can begin from a simple piece to a more advanced level of writing. It includes the organization of words, phrases, clauses and sentences.
\end{abstract}

Keyword: surface strategy taxonomy, writing

\section{INTRODUCTION}

English is an international language which has an important role in communication to interact with other people in the world. In English there are four language skills. Those are listening, speaking, reading, and writing. The writing has different activities from speaking, listening and reading. Writing needs to find the topic and also think about the content of writing, grammatical competence, the unity of the paragraph, the ideas, background of knowledge, and all the composition in written form to get a good writing. It is the reason why writing becomes the most difficult skill to learn, it is complicated and needs hard thinking.

The common problem that students always face in writing process is grammatical errors. They cannot use the structures correctly. The difficulties in applying the rules of the language in writing cause students who make errors. Dulay states that an error is a noticeable deviation from the adult grammar of a native speaker (1982 in Brown, 1994: 205). It means that students make errors 
because they less of grammatical knowledge. The students must learn more how to use the structure of sentence correctly.

By seeing students' errors, the researcher tries to collect information about students' errors in writing. Further analysis is needed in order to know in which language aspects they make errors and their frequency. Writing is a challenge for some students. Therefore, the students should have an extensive knowledge if they want to write anything because it will support their writing.

Error analysis has an important role to help the teacher to reveal what kind of error that mostly the students did in writing and the causes of the error they made by knowing the errors. The teacher could improve their method in teaching and would avoid the errors by giving the extensive materials about the errors in writing. Thus, one of the purpose of this research is help the teacher to know what the common error that students did in writing is.

The researcher applied errors analysis on surface strategy taxonomy. According to Corder (1981:36), surface strategy taxonomy is a superficial of error classification used as a starting point for systematic analysis. The researcher used surface strategy taxonomy as a starting point in the description of errors. Surface strategy taxonomy highlights the way surface structures are altered in specific and systematic ways. It involves four subcategories; they are omission, addition, misinformation, and mis ordering errors. The students' grammatical errors were analyzed and classified into those taxonomies.

For observing, the researcher chooses Kresna English Language Institute because Kresna is one of the most familiar grammar course in Kampung Inggris. Kresna English Institute also one of recommend English course according to some websites, such as; Darwis's Journey (2018), Seputar Kampung Inggris (2018), Kompasiana.com (2018).

It shows that many people have known about Kresna English Language Institute. Kresna English Language Institute also has some methods for learner to study comfortly. In the Kresna English Language Institute, one of the program for beginner who wants to learn about grammar and has long duration is PREPLANET. This program is conducted for a month. It also called as the first step before going to Planet Program which is one of the favorite programs in Kresna.

The researcher chooses Pre-Planet program because that is the first step for students to learn about grammar for long duration, it means that the students may learn grammar well. Thus, the researcher focuses on observing the beginner in writing skill. Before going to write well, the writer must know about the grammatical first. So that is why the researcher chose this program to know the beginner's knowledge in writing skill.

\section{METHODOLOGY}

This research used descriptive qualitative research. As stated by Bodgan and Taylor in Maleong (2004:3) qualitative methodology as a research procedure that procedure the descriptive data such written words or spoken words from people or activities that can be observed. Every research has certain informant to be observed. The informant was chosen to get the information about this study. They 
are owner, tutor and students of Pre-Planet program. In conducting the research, the researcher used triangulation as the instrument, they are:

\section{Document}

The document is stable, rich and support. It functions as evidence for testing and it has natural characteristic. Thus, that is appropriate to qualitative research. In this research, the researcher used documents as follow: The researcher used document analysis in the form of the students written. The, the researcher used the result of students' writing test to analyze by using Surface Strategy Taxonomy.

Percentage of Students Errors

\begin{tabular}{|c|c|c|c|}
\hline No & $\begin{array}{c}\text { Surface Strategy } \\
\text { Taxonomy }\end{array}$ & $\begin{array}{l}\text { Total of } \\
\text { Errors }\end{array}$ & $\begin{array}{c}\text { Percentage } \\
(\%)\end{array}$ \\
\hline 1 & Omission & & \\
\hline 2 & Addition & & \\
\hline 3 & Misformation & & \\
\hline 4 & Mis ordering & & \\
\hline & TOTAL & & \\
\hline
\end{tabular}

\section{Interview}

For interviewing, the researcher used semi structured interview. Interview did in the chosen interest area, and questions are formulated but the interviewer may modify the formal question during the interview process. The application of this technique in interview is to create relaxed and flexible situation to gain the information about the common grammatical error of students' ability in writing. The researcher makes the guideline interview for easier to get information.

The procedure of error analysis proposed by Ellis and Barkhuizen (2005) comprises the following five steps: (1) Collection of a data, (2) Identification of errors, (3) Description of errors, (4) Explanation of errors, (5) Errors evaluation.

\section{Collection of Data}

The researcher collected the students' writing test to be analyzed according to Dulay's theory. The students asked to write the sentences based on the topic. The students just get thirty minutes for doing the writing test. After that, they collect the paper to the tutor. Then, the researcher asked the paper to analyse.

\section{Identification of errors}

The errors were classified into four subcategories of surface strategy taxonomy by selecting and identifying the errors that belong to grammatical structure in students' writing. The errors found in clauses and sentences. Sentence may contain one error or more, and then they were analyzed separately.

\section{Description of errors}

The data were interpreted and described systematically according to the types of errors. The researcher tries to describe clearly to make other understand the result of research. 


\section{Explanation of errors}

The fourth was explaining the errors according to surface taxonomy strategy. The errors were identified and classified into the subcategories of surface taxonomy strategy, they are; omission, addition, misinformation and mis ordering.

\section{Errors evaluation}

The last step was errors evaluation by tabulating the errors to get the percentage of each subcategory. In this step, the frequency of errors were identified and the number of errors were presented in the forms of tables.

The procedure was expected to show the problem of students' writing in constructing clauses and sentences grammatically. The higher count indicated the prominent difficulties which is faced by the students in constructing clauses and sentences. The final step was making conclusion based on the research findings by describing the results of this research.

\section{RESEARCH FINDING}

\section{The Analysis Error of Students' Writing}

This research was analyzed based on Dulay et all theory, the surface strategy taxonomy which concerns on omission, addition, misinformation, and mis ordering errors. To find out the types of errors and how many errors on those components, the researcher documented the students' writing. After that, the percentage of each category of errors in their writings was counted. The last step was counting the percentage of each type of errors. The data from the students' writing are presented below.

Table 4.1

\begin{tabular}{|r|l|c|c|}
\hline No & $\begin{array}{c}\text { Surface Strategy } \\
\text { Taxonomy }\end{array}$ & $\begin{array}{c}\text { Total of } \\
\text { Errors }\end{array}$ & $\begin{array}{c}\text { Percentage } \\
(\mathbf{\%})\end{array}$ \\
\hline 1 & Omission & 37 & $17.21 \%$ \\
\hline 2 & Addition & 27 & $12.56 \%$ \\
\hline 3 & Misformation & 147 & $68.37 \%$ \\
\hline 4 & Mis ordering & 4 & $1.86 \%$ \\
\hline \multicolumn{2}{|c|}{ TOTAL } & 215 & $100 \%$ \\
\hline
\end{tabular}

Errors on Surface Strategy Taxonomy

Table 4.1 shows that 37 times of omission, 27 times were found in addition, 147 times errors were in misinformation and 4 times errors were found in mis ordering. Those errors described the problems which students face in their writing.

\section{Omission}

From the data research, it was found that the second highest percentage is omission. It was found 37 times or $17.21 \%$ out of the whole errors. The 
researcher found 1 omission error in MFA, LAM, UH and DZ's writing about article and also 3 omissions in MFV's writing about article too. In the IC's writing was found 5 times of omission, they are 4 errors in article and 1 error in preposition. There are 3 omissions error in NK's writing, 2 errors for article and 1 error is preposition. In ANP's writing there are 1 omission error about preposition. There are 2 omissions error in KN's writing about article. GS got 4 errors in her writing. They are 3 times in article and once about preposition. In the AR and AS' writing, the researcher found 2 errors about article and 1 error about preposition. The researcher also found 6 errors in NB's writing. She got once in article and 5 in the preposition. In the IAH's writing, there are 1 error about preposition. The last, the researcher found 1 omission error about article and 1 error about preposition. Thus, the researcher did not find about omission error in 7 students' writing.

\section{Addition}

The students committed 27 errors or $12.56 \%$ on their writing. The researcher found an addition error about word in the DZ and RH's writing. In the FM's writing, there are 6 errors was found. They are 1 error about word, 1 error about subject, 3 errors about auxiliary and an error about article. The researcher also found 1 error about auxiliary in DN's writing. In the NK's writing, there is an error about article. The researcher found 2 addition errors about auxiliary in SA's writing. There 4 errors about word and an error about auxiliary in GS' writing. The highest frequency of addition error was found in AR's writing. There are 8 errors found. 2 errors are about word, 2 errors are about subject, 2 errors are about auxiliary and 2 errors are about article. In the RD's writing there is an error about word and an error about auxiliary. The researcher did not find about addition error in the 13 student's writing.

\section{Misinformation}

Misinformation is the highest percentage that the researcher was found in students' writing. From the data, the students committed 147 times or $68.37 \%$ out of the whole errors. The researcher found there are 2 errors in MFA and LAM's writing. An error about subject verb agreement and an error about spelling. In the MFV and FM's writing was found an error about subject verb agreement and 3 errors about word choice. Oppositing with MFV and FM's writing, in the UH's writing was found 3 errors about subject verb agreement and an error about word choice There are 3 errors about subject verb agreement, 1 error about word choice and an error about spelling in the IC's writing. 14 errors was found in the DZ and DN's writing. The differentiation error between them is 7 times error of subject verb agreement and 7 times error of word choice happened in DZ's writing, whereas, 8 times error of subject verb agreement then 4 times error of word choice and 2 error about spelling happened in DN's writing. The researcher also found 4 errors about subject verb agreement and 4 errors about word choice in HR's writing. In the NK's writing, there are twice errors of subject verb agreement and twice errors of spelling happened. In the SA's writing, there are 4 errors about word choice and an error about subject verb agreement. Oppositing with SA's 
writing, the researcher found an error about word choice and 4 errors about subject verb agreement. There are 10 errors of misinformation were found in the KN's writing. 7 times in subject verb agreement and 3 times in word choice. GS did 15 times errors in her writing. They are 9 errors about subject verb agreement and 6 errors about word choice. In the AR's writing there are 2 errors about word choice. The researcher found 4 errors of subject verb agreement and 2 errors of word choice in the RH and MAM's writing. In the NB's writing was found an error of subject verb agreement, 2 errors of word choice and an error of spelling. There only 2 errors of subject verb agreement were found in the IA's writing. The highest frequency of misinformation was found in AS' writing by the number were found 19 errors. 11 errors of subject verb agreement, 7 errors of word choice and an error of spelling. The lowest frequency of misinformation was found in ANP's writing by once error happened about subject verb agreement.

\section{Mis ordering}

From the data, the researcher was found 4 times or $1.86 \%$ errors were found in mis ordering. This error comprised the incorrect placement of a morpheme or group of morphemes in an utterance or writing. The researcher found in DN, GS, ARH and MAM writing.

\section{The Factors Happen in Students' Writing}

In this research, the researcher used document and interview as the instrument. From the data of those instruments, the researcher found:

$>$ Omission. Based on the data, mostly the students did not put the article like in the sentence that need it. The students often forgot some important parts in a sentence, although it is so simple.

Addition. Some of the students used the word that has same meaning in the one sentence. Based on the data the students also repeat the word that actually they can use once in the sentence.

$>$ Misinformation. Based on the data, the students missed in using subject verb agreement, word choice and spelling.

- Mis ordering. From the data, mis ordering is the lowest error that students did in their writing. As the researcher explained, the error comprised the incorrect placement of a morpheme or group of morphemes in an utterance or writing.

Based on the instrument above, the factors happen in the students' writing are because of the students do not know well about how to use the structure of sentence, the vocabulary that the students do not know before even how to spell it. The students also thought that article is easy but they cannot use it well.

\section{DISCUSSION OF FINDING}

The Analysis of Students' Writing

Omission

The researcher found $17.21 \%$ or 37 errors of omission in the students' writing. There were found 24 times error about article. Then, 13 times error about preposition. Article and preposition is the simple part of writing, but the students 
still get wrong in use it. According to Swan (in Harmer, 2002: 15), good rule include 'simplicity' (it may cause problems), 'truth' (because clearly some rules are more 'true' than others), 'clarity' (because rules that are unclear help nobody) and 'relevance' (because there are some things which a teacher or student probably does not really need to know). It means that the most simple part of writing must be clear in order to the reader get the point of writing.

\section{Addition}

There were found 27 times errors of addition or $12.56 \%$ in the students writing. There are 4 kinds of addition; word, subject, auxilary and article. According to Dulay Burt, and Krashen (1982: 146-191), addition errors are characterized by the presence of an item which must not appear in a well-formed utterance. Based on the data, the students presence the word that has same meaning. That is the highest number was found. The number of presenting the word has same as the number of presenting the auxilary. There are 10 times. The researcher also found 3 errors in the subject presenting and 4 times in the articles.

According to Barkhudarov (in Iriskulov 2006: 13), a language has structure category which represent linguistic phenomenon that has a general structure meaning consisting of at least two particular meanings that are opposed to eachother and that have constant means of their own to express them. It means that in a sentence must has a general structure meaning consisting to express the writing.

\section{Misinformation}

This error is the highest percentage in the students writing. There were 147 times or $68.37 \%$ out of the whole errors. There are 3 kinds of misinformation error that was found. They are subject verb agreement, word choice and spelling. The highest number that was found is subject verb agreement, there are 80 times in the students writing. 58 times in the word choice of error. Only 9 times were found in the spelling error.

According to David Crystal (2011), writing a composition with vocabulary and structure which the student has either learnt to use orally or written exercises for each lesson. According to Thornbury (2004:1), structure is partly the study of what forms (or structures) are possible in a language. It means that structure is concerned with analysis of the sentence which is describe the rules how language sentences are formed. Knowledge of good structure will influence the coherence of the piece of writing. By using correct rule of structure, writers will have good writing.

\section{Mis ordering}

The lowest precentage of error is Mis ordering. According to Dulay Burt, and Krashen (1982: 146-191, mis ordering errors are characterized by the incorrect placement of a morpheme or group of morphemes in an utterance. There are 2 kinds of mis ordering that the researcher found. They are word and auxiliary. The researcher found 3 times of word and once of auxiliary of incorrect placement. According to Ur (1993: 4), structure as the way a language manipulates and combines words (or bits of words) in order to form longer units 
of meaning. It means that structure tells how the rules of language actually works, they arrange and shape words.

\section{The Factors Happen in Students' Writing}

Based on the instrument and data the factors happen in the students' writing are because of the students do not know well about how to use the structure of sentence, the vocabulary that the students do not know before even how to spell it. The students also thought that article is easy but they cannot use it well. Writing can begin from a simple piece to a more advanced level of writing. It includes the organization of words, phrases, clauses and sentences.

According to Alamargot et al (2010), developing writing is related to the writer's knowledge of language and writing exposure. It means that writing process is the way of writers give their ideas and messages to readers in the form of text. Based on the finding research that the researcher was found, the factors happen in students' writing is the students less of knowledge about rules and form of stucture in writing.

According to Harmer (2002 : 255), writing has a number of conventions which separate it out from speaking. A part from differences in structure and vocabulary, there are issues of letter, word and text formation, manifested by handwriting, spelling and punctuation. It means that writing offers opportunities to increase students' vocabulary, knowledge of structure and develops their understanding of how things are expressed and how well students' message is understood in the written form.

\section{CONCLUSION}

$>$ Omission. From the data research, it was found that the second highest percentage is omission. It was found 37 times or $17.21 \%$ out of the whole errors. Omission is the error which is characterized by the absence of an item that must appear in a well-formed utterance. The errors mostly about the articles

Addition. The students committed 27 errors or $12.56 \%$ on their writing. The errors were characterized by the presence of new structure of morpheme or phrases in a correct linguistic form. The highest percentage of addition errors were found in the research data was simple addition. Simple addition errors characterize all addition errors. It is the use of an item which should not be appeared in a well-formed utterances.

- Misinformation. Misinformation is the highest percentage that the researcher was found in students' writing. Mis formation errors comprised the use of the wrong form of the morphemes or structure. It is occurred when the learner supplies something although it is incorrect. From the data, the students committed 147 times or $68.37 \%$ out of the whole errors.

Mis ordering. From the data, the researcher was found 4 times or $1.86 \%$ errors were found in mis ordering. This error comprised the incorrect placement of a morpheme or group of morphemes in an utterance or writing. 
The factors of those errors because of the students do not know well about how to use the structure of sentence, the vocabulary that the students do not know before even how to spell it. Writing can begin from a simple piece to a more advanced level of writing. It includes the organization of words, phrases, clauses and sentences.

\section{REFERENCES}

Alamargot, Dennis and Fayol, Michel. 2010. Modelling Development of Written Composition. Journal of Second Language Writing. 23-47

Alice, Oshima. 2007. Introdution to Academic Writing. USA: Pearson Education. Anas Sudjono. 2006. Pengantar Statistik Pendidikan. Jakarta: PT Raja Grafindo Persada.

Brown, H. Douglas. 1994. Principles of Language Learning and Teaching. 3rd edition. Englewood Cliffs, New Jersey: Prentice Hall Inc.

Brown, Douglas H. 2000. Principles of language learning and teaching. San Fransisco, State University: Pearson Education

Brown, H. D. 2001. Teaching by Principles: An interactive approach to language pedagogy (second edition). New York: Longman.

Corder, S. Pit. 1981. Introducing Applied Linguistics. Harmondsworth: Penguin Book Ltd.

Creswell, John W. 2014. Research Design Qualitative, Quantitative, and Mixed Methods Approaces ( $4^{\text {th }}$ Ed). London: Sage.

Crystal, David. (2011). A Dictionary of Linguistics and Phonetics. USA: Cambridge University Press.

Dulay, H., Burt, M., Krashen S. 1982. Language Two. Oxford: Oxford University, Inc.

Grace, E. 2006. Look Ahead.Erlangga. Jakarta.

Harmer, Jeremy. 2002. The Practice of English Language Teaching 3rd Edition. London: Longman.

Iriskulov, A., T. 2006. Theoritical Grammar of English. Uzbek State World Languages University

Lee, I. 2004. Error Correction in L2 Secondary Writing Classrooms: The case of Hong Kong. Journal of Second Language Writing, 13(4), 285-312.

Siahaan, Sanggam and Kisno Shinoda. 2008. Generic Text Structure. Yogyakarta: Graha Ilmu.

Suryadi and Junaida. 2011. Complete English Grammar (Belajar Bahasa Inggris Awal Sampai Mahir). Yogyakarta: Pustaka Belajar.

Taylor, J., R. 1997. An Introduction to Error Analysis: The Study of Uncertaintiesin Physical Measurements 2nd Edition. Colorado: University Science Book.

Thornbury, S. 2004. Natural Grammar: The Keywords of English and How They Work. Oxford: Oxford University Press

Ur, P. (1988) Grammar Practice Activities: a practical guide for teachers. Cambridge: Cambridge University Press.

Wy. Dirgeyasa. 2014. College Academic Writing: A Genre-Based Perspective. Medan: Unimed Press. 